\title{
野外に生息するマダニ類に対する数種殺虫製剤の防除効果
}

\author{
橋本知 幸*,1）數間 亨 ${ }^{1 ｝ \text { 武藤敦彦1）皆川恵子1） 永廣香菜 }{ }^{1)}$ \\ 當山啓介 ${ }^{2}$ 足立雅也 ${ }^{3)}$ 池田文明 ${ }^{3)}$ 駒形 修 ${ }^{4)}$ \\ 冨田隆史 ${ }^{4}$ 森川 茂 ${ }^{5)}$ 澤邊京子4) \\ 1) 一般財団法人日本環境衛生センター環境生物部（†210-0828 川崎市川崎区四谷上町 10-6） \\ 2) 東京大学大学院農学生命科学研究科附属演習林千葉演習林（干299-5503 鴨川市天津 770） \\ $\left.{ }^{3}\right)$ 日本防疫殺虫剤協会（广101-0035 千代田区神田紺屋町 46） \\ 4) 国立感染症研究所昆虫医科学部（广 162-8640 新宿区戸山1-23-1） \\ 5) 国立感染症研究所獣医科学部（广162-8640 新宿区戸山1-23-1）
}

（受領：2014年12月31日；登載決定：2015年2月9日）

\section{Field evaluation of suppression effect of acaricide formulations against ticks}

\author{
Tomoyuki Hashimoto*, 1), Tohru Kazuma ${ }^{1)}$, Atsuhiko Muto ${ }^{1)}$, Keiko Minagawa ${ }^{1)}$, \\ Kana NAGAHIro $^{1)}$, Keisuke Toyama ${ }^{2)}$, Masaya AdACHI ${ }^{3)}$, Fumiaki IkedA $^{3)}$, \\ Osamu Komagata ${ }^{4)}$, Takashi Tomita ${ }^{4)}$, Shigeru Mori ${ }^{5)}$ and Kyoko SawabE ${ }^{4)}$ \\ * Corresponding author: Environmental Biology Department, Japan Environmental Sanitation Center, \\ 10-6 Yotsuyakamicho, Kawasaki-ku, Kawasaki 210-0828, Japan \\ (E-mail: tomoyuki_hashimoto@jesc.or.jp) \\ 1) Environmental Biology Department, Japan Environmental Sanitation Center, \\ 10-6 Yotsuyakamicho, Kawasaki-ku, Kawasaki 210-0828, Japan \\ 2) The University of Tokyo Chiba Forest, Graduate School of Agriculture and Life Sciences, \\ 770 Amatsu, Kamogawa 299-5503, Japan \\ 3) Hygienic Insecticide Industrial Association of Japan, 46 Kandakonyacho, Chiyoda-ku 101-0035, Japan \\ ${ }^{4)}$ Department of Medical Entomology, National Institute of Infectious Disease, \\ 1-23-1 Toyama, Shijuku-ku 162-8640, Japan \\ 5) Department of Veterinary Science, National Institute of Infectious Disease, \\ 1-23-1 Toyama, Shijuku-ku 162-8640, Japan
}

(Received: 31 December 2014; Accepted: 9 February 2015)

\begin{abstract}
A field evaluation of the acaricidal effect on ticks was conducted in Chiba Prefecture in 2014. Eleven formulations of organophosphates and pyrethroids, including emulsifiable concentrate (EC), flowable (FL), dust and $\mathrm{CO}_{2}$ gas formulation, were evaluated simultaneously. These formulations were respectively applied to zones $2 \mathrm{~m}$ wide by $17-60 \mathrm{~m}$ long with dosages between $0.05-0.25 \mathrm{~g} \mathrm{AI} / \mathrm{m}^{2}$, which are the recommended dosages for cockroach control in buildings. The numbers of ticks collected by the dragging method with flannels were compared between pre- and post-treatment. The genus Haemaphysalis and Amblyomma were captured during the test period. All the formulations drastically suppressed the tick density on day 1 . High reduction rates of more than $90 \%$ were observed until day 4 in all formulations, and persistence for at least for 31 days was recognized in fenitrothion EC, FL and fenthion dust. Phenothrin $\mathrm{CO}_{2}$ gas formulation that flows in the air with little residue in the soil or on foliage also yielded a long suppression effect at a dosage of $0.05 \mathrm{~g} \mathrm{AI} / \mathrm{m}^{2}$. Tick infestation from outside the test plot seemed to be feeble after the treatment. These results suggested that all the formulations achieved superior suppression effect on the ticks.
\end{abstract}

Key words: tick, acaricide, organophosphate, pyrethroid, suppression, persistence, infestation

\section{緒言}

2013年1月，国内で初めて確認された重症熱性血小板減少 症候群（SFTS）は，その後，西日本を中心に症例が増加し， 最初の症例から 2014 年 11 月末までに, 感染者 100 名以上, 死亡は30名以上に達している（国立感染症研究所, 2014). 野生動物からマダニによって媒介される感染症は日本紅斑熱 やライム病なども知られるが，SFTS症例の急増は住民や行
政に危機感をもたらし，各地でマダニ対策の必要性が生じて いる.

山林に広く分布するマダニ対策としては, マダニ侵淫地域 への無用な立入りの回避, 忌避剂の使用など, マダニに咬着 されないための方策が中心である. しかし人の通行が多く被 害リスクが高い場合には，その通行箇所周辺の植生の刈り込 み, 野生動物の侵入防止柵の設置, 殺虫剂の処理など積極的 な対策を考える必要が出てくる，米国ではそれらの費用対効 
果を数年に渡って検証した事例が知られており（Bloemer et al., 1990; Stafford III, 2004), 殺虫剤散布は費用, 労力が比較的 少なく, マダニの密度を効果的に低減させることができる手 段の一つとして考えられている. 近年は従来の殺虫製剤以外 にも, 植物由来成分による野外防除効果（Dolan et al., 2009; Bharadwaj et al., 2012）も検証されている.

米国では, 野外のマダニに対する殺虫剤散布による防除 効果に関する研究は多い（Mount, 1981; Mount and Whitney, 1984; Schulze et al., 1994; Schulze et al., 2000; Hughes et al., 2014) が, わが国では畜産関連施設以外ではマダニ駆除はほとんど 実施されてこなかった。 山野における事例としては, 岡村 ら（1963）によるツツガムシ駆除のための大規模な殺虫剂散 布実験が知られる程度であまり報告されていない，畜産関連 施設においても, 現在の傾向としてはプアオンやイヤータッ グなど, 畜体への直接処理でマダニ駆除を実施しているケー スが多く, 牧野への散布は少なくなっている（吉田，1975； 佐々木ら, 1998; Tamura et al., 2004). SFTS症例の増加を踏ま えて, 日本では山林や住宅地周辺でマダニ防除を標榜する殺 虫剂は, 医薬品医療機器等法（旧薬事法）上の承認を得るこ とが必要となり, 厚生労働省はその迅速審査の通知を発出 し, その承認申請にあたっては効力を確認した資料の提出が 要求されている（厚生労働省, 2013a, b).

このため筆者らは房総半島の山林において複数の殺虫製剤 の実地における防除効果を評価した. 当該地域はシカ, イノ シシ等の中・大型野生動物が多数生息し（浅田, 2011), こ れらの動物に寄生するマダニ類の密度も高いことが知られて いる（森・藤曲, 1994; 角田, 2012). このようなマダニ密 度が高い地域で効力を評価する機会は貴重であり, 今後のマ ダニ対策策定への有用性が高いと考えられるので報告する.

\section{材料と方法}

\section{対象地および試験期間}

試験は千葉県鴨川市から君津市にまたがる東京大学千葉演 習林内の郷台林道沿いを対象地とした。当該地域はシイ, 力 シ等の照葉樹にアカマツ, コナラなどを加えた林が広がる が, 薬剤処理は日当りの悪い林縁部の落葉が堆積した箇所
や，ある程度日が当たって草本類の生える場所であった. 試 験期間は 2014年5月 18 日〜 6月 19日であった.

\section{供 試 薬 剂}

供試薬剤は医薬品医療機器等法によりマダニに対する効能 効果が承認された有機リン（フェニトロチオン，フェンチオ ン), ピレスロイド (ペルメトリン, フェノトリン, テトラ メスリン (=フタルスリン), エトフェンプロックス), およ びそれらの混合市販製剤で, 液剤 8 製剤（乳剤，フロアブル 剂), 粉剂 2 製剂, 炭酸ガス製剂 1 製剂の合計 11 製剂とした。 各試験区の長さ, 液剤の希釈倍率, 単位面積当たり希釈液 （液剂）または製剤（粉剤・炭酸ガス製剤）処理量, 有効成 分換算薬量は Table 1 に示した.

\section{試 験 方 法 \\ 1）処理前調查}

上記林道沿いの落葉および植生のある平坦または傾斜地 に幅 $2 \mathrm{~m} \times$ 長さ 17〜 66 $\mathrm{m}$ の帯状に, 試験区を合計 26 区設定し た. 試験区の長さは下記の旗ずり法によって, 散布前日に得 られるマダニ数が概ね 10 頭以上になるように決定し, 各処 理区を割り振った。このうち4区を対照区（水処理2区，無 処理2区）とし，その他22区を薬剤処理区とした。薬剤処 理前日の 11 時〜 15 時の間に, 各区画の地面に幅 $70 \mathrm{~cm} \times$ 長さ $100 \mathrm{~cm}$ の白フランネル布を棒に固定して, その全面を接地さ

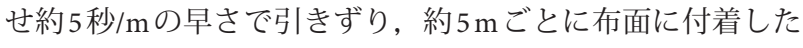
マダニ数を計数した. 布は前後左右に振らずに一方向にのみ 引きずった．引きずる位置は各区画の中央部分とした．この 際, 草丈 $30 \mathrm{~cm}$ 程度までの草本類はその上から覆いかぶせる ように移動し，木本や倒木がある場合はそれらを回避して試 験区から出ないようにした，布上のマダニは目視により若 虫・成虫のみを計数後, 同じ区画内に放した. なお各区と も, 薬剤污損していない布を使用した。

\section{2) 薬剂処理}

薬剤処理は2014年5月19日に実施した。供試薬剤 11 製剤 について, 各々 2 試験区を割当て, 反復とした。このうち液

Table 1. Test agents and application condition.

\begin{tabular}{|c|c|c|c|c|c|}
\hline \multirow{2}{*}{ Test agent* } & \multirow{2}{*}{ Dilution rate } & \multirow{2}{*}{$\begin{array}{l}\text { Amount applied } \\
\qquad\left(/ \mathrm{m}^{2}\right)\end{array}$} & \multirow{2}{*}{ Dose $\left(\mathrm{g} \mathrm{AI} / \mathrm{m}^{2}\right)$} & \multicolumn{2}{|c|}{ Length of test plot** (m) } \\
\hline & & & & Replication 1 & Replication 2 \\
\hline Fenitrothion 10\% EC & $\times 20$ & $50 \mathrm{~mL}$ & 0.25 & 60 & 30 \\
\hline Fenitrothion $10 \% \mathrm{FL}$ & $\times 20$ & $50 \mathrm{~mL}$ & 0.25 & 47 & 44 \\
\hline Fenitrothion $5 \%$, Tetramethrin $0.5 \%$ EC & $\times 10$ & $50 \mathrm{~mL}$ & Feni 0.25 , Tetra 0.025 & 24 & 26 \\
\hline Fenthion $5 \%$,Tetramethrin $0.5 \%$ EC & $\times 5$ & $50 \mathrm{~mL}$ & Fen 0.5 , Tetra 0.05 & 17 & 21 \\
\hline Phenothrin 10\% EC & $\times 20$ & $50 \mathrm{~mL}$ & 0.25 & 24 & 26 \\
\hline Permethrin 5\% EC & $\times 20$ & $50 \mathrm{~mL}$ & 0.125 & 33 & 49 \\
\hline Etofenprox 7\% EC & $\times 10$ & $50 \mathrm{~mL}$ & 0.35 & 30 & 24 \\
\hline Etofenprox 5\% EC (+S421) & $\times 30$ & $50 \mathrm{~mL}$ & 0.083 & 21 & 52 \\
\hline Control (water) & water only & $50 \mathrm{~mL}$ & - & 52 & 51 \\
\hline Fenitrothion $1.5 \%$ dust & direct & $20 \mathrm{~g}$ & 0.3 & 43 & 40 \\
\hline Fenthion $1 \%$ dust & direct & $30 \mathrm{~g}$ & 0.3 & 46 & 26 \\
\hline Phenothrin $1 \% \mathrm{CO}_{2}$ gas & direct & $5 \mathrm{~g}$ & 0.05 & 36 & 23 \\
\hline Control (untreated) & - & - & - & 66 & 22 \\
\hline
\end{tabular}

\footnotetext{
*EC: Emulsifiable Concentrate, FL: Flowable. Tetramethrin $=$ Phthalthrin. ${ }^{* *}$ Width of all test plot was $2 \mathrm{~m}$.
} 
剂は容量比で所定倍率に水で希釈し, 全自動噴霧器（B\&G 製; エクステンダーバン）により，地面から 15～50 cm の距 離から区画内にできるだけ均一に処理した。粉剤は散粉器 （共立製；D-9）を用い，炭酸ガス製剂は専用ノズルを用い て同様に処理した．対照区は水処理区のみ, $50 \mathrm{~mL} / \mathrm{m}^{2}$ の割 合で水を全自動噴霧器で散布した．処理薬量は医薬品医療機 器等法で既承認のゴキブリ駆除を目的とした残留処理や空間 処理等の用法用量とした (Table 1).

\section{3）処理後調査}

薬剂処理の $1,4,7,16,31$ 日後に, 処理前と同様の方法で試 験区内のマダニ数を計数した。処理前後の調査は晴れまた は量りの日に実施し, 調査時の対照区付近の気温は18.0 $25.7^{\circ} \mathrm{C}$ であった. 薬剤処理後 $10 \mathrm{~mm}$ 以上の降雨は, 処理後 2 , $3 ， 8 ， 17 ， 18 ， 19 ， 23,24$ 日目にあり，18，19日目は $50 \mathrm{~mm}$ 以上の 降水量であった（気象庁君津市坂畑観測所データ）。なお, マダニの種類構成をみるために，薬剤処理日および7日後に $4 つ の$ 対照区の近傍（距離は合計で 20〜 30m）で, 旗ずり法 によって得られたマダニの若虫と成虫を採集同定した他，31 日後には各試験区内で採集されたマダニを同定した.

\section{4）効力評価}

試験区の長さが異なるため，旗ずり法によって得られたダ 二総数を距離 $10 \mathrm{~m}$ 当たりのダ二数に換算し, 処理区におけ るダニ数の減少率を, 各区の処理前後のダニ数から, Mount （1981）に従い，下式により算出した。

$$
\text { 減少率 }(\%)=\left\{1-\left(T_{n} / T_{0}\right) /\left(C_{n} / C_{0}\right)\right\} \times 100
$$

$T_{n}$ : 処理区 $n$ 日後平均ダ二数, $T_{0}$ : 処理区処理前平均ダ二数 $C_{n}$ : 対照区 $n$ 日後平均ダ二数, $C_{0}$ : 対照区処理前平均ダ二数

また，処理後調査で得られたダニ数データ（反復 2 回 $\times$ 観 察5回）を試験区間で多重比較した（Steel-Dwass法）。比較 する対照区は液剤（8製剤）では水処理対照区，粉剤と炭酸 ガス製剤（計3製剂）は無処理対照区とした。さらに，処 理前密度が防除効果に及ぼす影響を検討するために，反復 ごとに処理前ダニ数と処理後合計ダニ数の相関を検討した
（Spearman 順位相関検定）.

\section{結果}

薬剂処理前の各区のダニ数は $3.31 \sim 16.50$ 頭 $/ 10 \mathrm{~m}$ であった (Table 2). 薬剤処理区の 1 日後のダ二数は例外なく顕著に減 少し，速効的な防除効果が見られた．90\%以上の減少率は全 ての区で4日後まで見られ，フェニトロチオン乳剂・フロア ブル剂，フェンチオン粉剤では少なくとも 31 日後まで $90 \%$ 以上を維持し続けた（Table 2). ただし，処理後日数の経過 を考慮せずに試験区間で多重比較すると，薬剤処理区間で は全ての組み合わせで有意差は認められなかったが，フェ ンチオン・テトラメスリン混合乳剂, フェノトリン乳剂は7 ～16日後のダ二数増加の影響により, 対照区との有意差も 認められなかった（Fig. 1).このため, 各処理区の処理後合 計ダニ数を処理前ダ二数と比較した結果, 高い相関 $(n=22$, $r s=0.787, p=0.0003 ）$ が見られ，処理前密度が高い場合，処 理後の捕獲数も多くなる傾向が見られた（Fig. 2).

期間中に見られたマダニの種類構成は Table 3の通りで, 処理前はオオトゲチマダニHaemaphysalis megaspinosa Saitoが やや多かったが，処理後には対照区でも本種は得られず, フタトゲチマダニH. longicornis Neumannが多い傾向にあっ た。なお，処理 31 日後の試験区外では，ここに示された種 以外にヤマトマダニIxodes ovatus Neumann, ツノチマダニH. cornigera Neumannが得られた.

\section{考察}

\section{1） 速効性と持続性}

有機リン剤とピレスロイド剂の処理面にチャバネゴキブ リなどを接触させると, 一般的には後者のほうが速効的に 作用する（新庄ら，2013）。また, 北岡・藤崎（1971）は複 数の室内試験において, フタトゲチマダニ幼虫やオウシマ ダニBoophilus microplus (Canestrini) 飽血雌成虫では, ピレ スロイドのほうが有機リンよりも速効的であることを示し ている. 今回の条件ではこれらの差を検出することはでき ず, どの薬剤もほぼ一様に, 1 日後に高い減少率を示した. Mount（1981）は，有機リン剂のダイアジノン粒剤と乳剤の

Table 2. Changes of mean numbers of ticks of 2 replications and percentage reduction.

\begin{tabular}{lcccccc}
\hline \hline \multirow{2}{*}{ Test agent } & \multicolumn{5}{c}{ Mean numbers of ticks per 10 m length (\% reduction) } \\
\cline { 2 - 7 } & day -1 & day 1 & day 4 & day 7 & day 16 & day 31 \\
\hline Fenitrothion 10\% EC & 5.33 & $0.08(98.0)$ & $0.17(95.2)$ & $0.17(94.1)$ & $0.00(100)$ & $0.00(100)$ \\
Fenitrothion 10\% FL & 4.18 & $0.00(100)$ & $0.00(100)$ & $0.00(100)$ & $0.21(93.1)$ & $0.00(100)$ \\
Fenitrothion 5\%, Tetramethrin* 0.5\% EC & 9.44 & $0.21(97.2)$ & $0.21(96.6)$ & $0.38(92.3)$ & $0.83(88.0)$ & $0.82(73.1)$ \\
Fenthion 5\%, Tetramethrin* 0.5\% EC & 16.50 & $0.00(100)$ & $0.00(100)$ & $0.48(94.5)$ & $2.86(76.5)$ & $2.07(61.0)$ \\
Phenothrin 10\% EC & 8.24 & $0.00(100)$ & $0.00(100)$ & $1.96(55.1)$ & $0.59(90.2)$ & $0.96(63.7)$ \\
Permethrin 5\% EC & 5.70 & $0.00(100)$ & $0.00(100)$ & $0.00(100)$ & $0.00(100)$ & $0.25(86.2)$ \\
Etofenprox 7\% EC & 8.29 & $0.00(100)$ & $0.00(100)$ & $0.00(100)$ & $0.00(100)$ & $1.17(56.3)$ \\
Etofenprox 5\% EC (+S421) & 6.68 & $0.00(100)$ & $0.00(100)$ & $0.95(73.0)$ & $0.24(95.2)$ & $0.57(73.4)$ \\
Control (water) & 3.31 & 2.63 & 2.14 & 1.75 & 2.44 & 1.07 \\
\hline Fenitrothion 1.5\% dust & 4.73 & $0.00(100)$ & $0.00(100)$ & $0.33(92.5)$ & $0.28(93.8)$ & $0.33(85.3)$ \\
Fenthion 1\% dust & 6.02 & $0.00(100)$ & $0.00(100)$ & $0.19(96.6)$ & $0.00(100)$ & $0.11(96.2)$ \\
Phenothrin 1\% CO ${ }_{2}$ gas & 7.52 & $0.00(100)$ & $0.36(96.0)$ & $0.50(93.0)$ & $2.10(71.0)$ & $0.43(88.0)$ \\
Control (untreated) & 3.79 & 2.42 & 4.47 & 3.56 & 3.64 & 1.82 \\
\hline
\end{tabular}

\footnotetext{
${ }^{*}$ Tetramethrin $=$ Phthalthrin.
} 
Table 3. Deveropmental stages and numbers of ticks captured near/in the control plots during study period.

\begin{tabular}{|c|c|c|c|c|}
\hline \multirow{2}{*}{ Species } & \multirow{2}{*}{$\begin{array}{c}\text { day } 0 \\
\text { Near control }\end{array}$} & \multirow{2}{*}{$\begin{array}{c}\text { day } 7 \\
\text { Near control }\end{array}$} & \multicolumn{2}{|c|}{ day 31} \\
\hline & & & In control & In treatment \\
\hline Haemaphysalis flava & $\mathrm{N} 2, \mathrm{~A} 1$ & $\mathrm{~N} 1$ & & A1 \\
\hline H. kitaokai & A3 & & & \\
\hline H. longicornis & $\mathrm{N} 2$ & $\mathrm{~N} 8, \mathrm{~A} 2$ & $\mathrm{~N} 12, \mathrm{~A} 3$ & $\mathrm{~N} 23, \mathrm{~A} 13$ \\
\hline H. megaspinosa & N6, A2 & & & \\
\hline Amblyomma testudinarium & & $\mathrm{A} 1$ & N1 & \\
\hline
\end{tabular}

$\mathrm{N}$ : nymph, A: adult. Larvae were not counted throughout the study. Values in day 0 and day 7 show the numbers of ticks near the control plots (total 20-30 m long). Values in day 31 show total numbers of ticks in the control (4 plots) and in the treatment (22 plots).

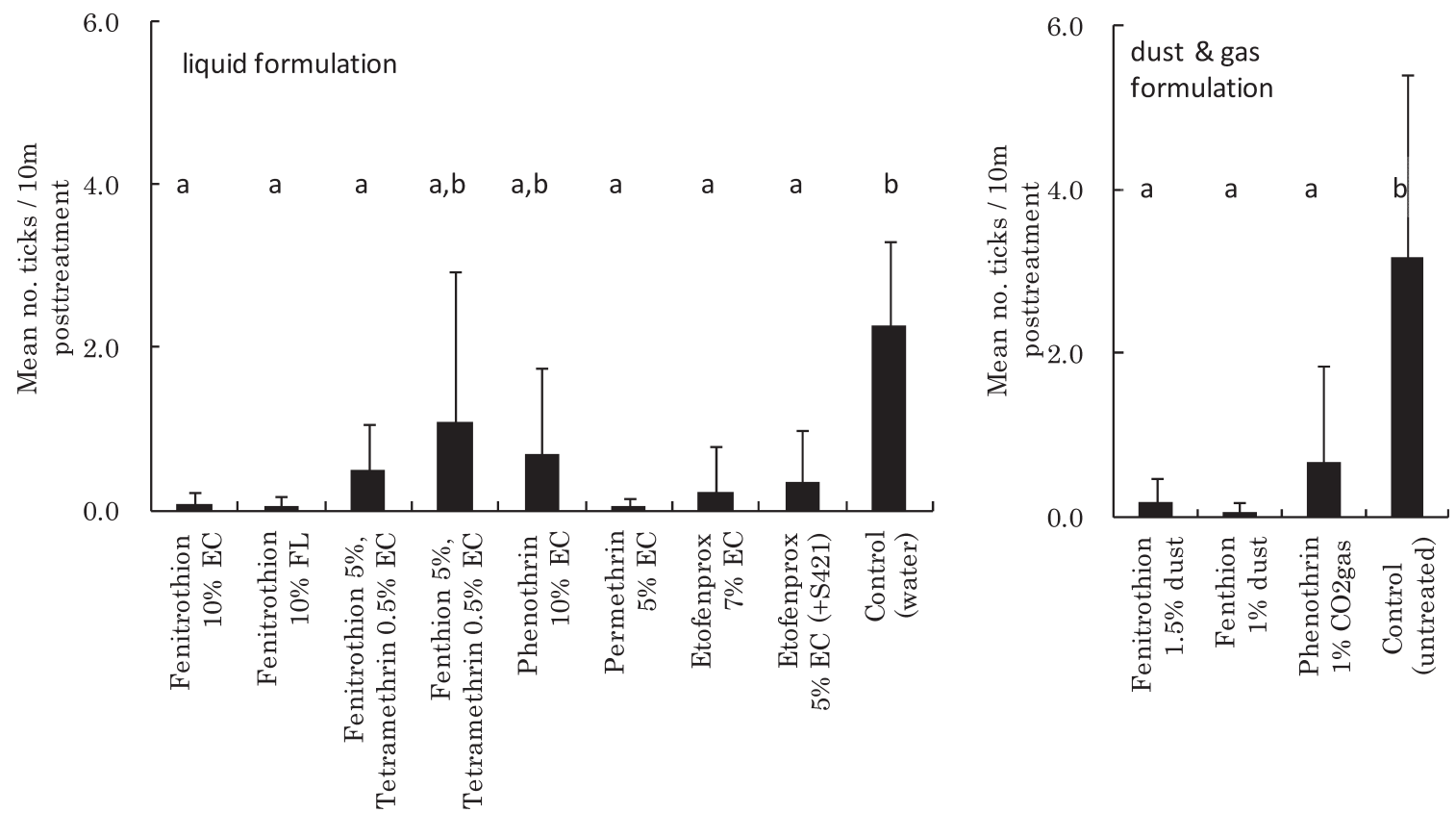

Fig. 1. Comparison of the numbers of ticks post treatment.

Values are mean \pm S.D. of 2 replications and 5 observations. No significant differences are observed among formulations with same letters (Steel-Dwass' test, $p<0.05)$.

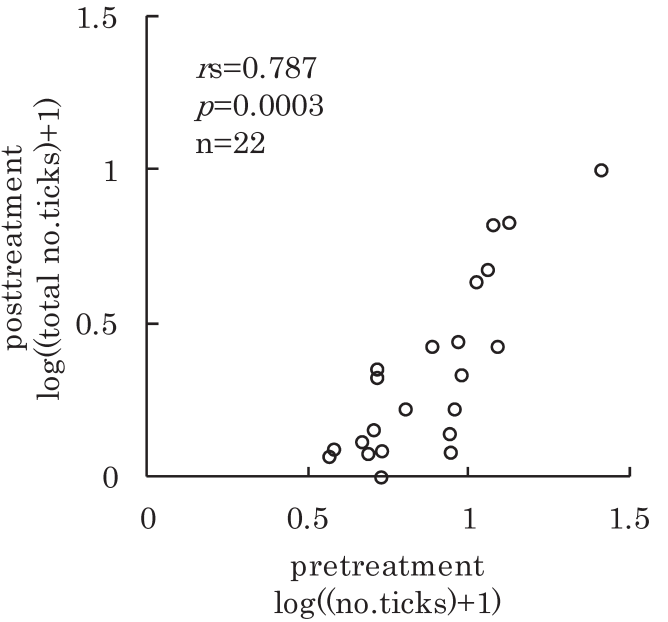

Fig. 2. Correlation of the numbers of ticks between pre- and post-treatment (total).

rs means Spearman's correlation coefficient.
速効性を実地試験により比較し，粒剂は処理後の降雨などに よってマダニの潜み場所である土壌表面や落葉層への有効成 分の溶出が促進されるが, 降雨がない条件では効力発現が 遅くなるとしている，粉剤も粒剂同様, 有効成分を乾燥状 態で保持しているため, 液剤よりも遅効的な結果となる可 能性があった. 今回, 薬剤処理 1 日後までの間に降雨はな かったが, 1 日後に全ての粉剤処理区でダニ数 0 を示したこ とから, 20〜30 g/ $\mathrm{m}^{2}$ という処理量であれば, マダニに対し て速効性を発揮することを示唆している. 一方, 炭酸ガス製 剂では成分の担体は液体ではなく炭酸ガスである. その粒 子は $0.3 \sim 3 \mu \mathrm{m}$ と細かく, 液剂と異なり, 大部分が気層を短 時間で通過する。 このため, 液剂以上にすばやく拡散する が, 落葉の隙間のような部分には到達しないか, 到達した としても有効成分の暴露量が低いのではないかという不安 があった. しかし処理 1 日後から高い減少率を示したことか ら, マダニへの暴露は十分であったものと判断された。 な お, 今回の処理薬量は米国の野外マダニを対象にした先行 研究に比べて一部の製剂を除き，高いものであった（Mount, 1981; Mount and Whitney, 1984; Schulze et al., 2000; Hughes et al., 
2014). Hughes（2014）は cypermethrin では $0.1 \mathrm{~g} \mathrm{AI} / \mathrm{m}^{2}$ 未満の 処理, $\lambda$-cyharothinでは $0.015 \mathrm{~g} \mathrm{AI} / \mathrm{m}^{2}$ 末満の処理（いずれも ピレスロイド）で, 最短でも 6 週間の効力持続があるとして いる.また, Mount（1981）は野外散布時のIxodes scapularis Sayに対する $90 \%$ 有効薬量 $\mathrm{ED}_{90}$ を，ペルメトリン乳剂を使 用した場合が $0.017 \mathrm{~g} \mathrm{AI} / \mathrm{m}^{2}$, 有機リンのダイアジノン乳剂が $0.072 \mathrm{~g} \mathrm{AI} / \mathrm{m}^{2}$ と算出しており, 今後, より低薬量での効力評 価が課題である.

一方, 野外での殺虫剤の効力持続性については, 散布回数 を減らす観点では長いほうが望まれるが，非標的生物等への 影響を減らす観点では高リスクの時期だけ効力を発揮し，害 虫密度の低下後は速やかに分解されるべきであろう。一般的 にマダニの生息環境は生物多様性が高く, 他の方法と組合せ て対応することが望まれる. このため, 処理後1力月間効力 が持続すれば十分であると考える。土堙表面や水中におい て, 殺虫剂の有効成分は光分解や加水分解によって徐々に失 活するが (Mikami et al., 1985, Sakata et al., 1992), 初期薬量が 多ければ, 効力持続性も長くなることが予測される. フェニ トロチオン乳剤・フロアブル剤, フェンチオン粉剤では 31 日後でも $90 \%$ 以上の高い減少率を維持しており, さらに長期 に渡って効果が見られた可能性はあるだろう。 また, 効果が 持続したもう一つの要因としては, 処理区へのマダニの侵入 状況が挙げられる. 今回の試験区は带状の狭いエリアで, 試 験区周辺のマダニ生息密度は高いと思われ，マダニは侵入し やすい状況であったと考えられる。一方で, 残効性は低いと 思われる炭酸ガス製剤だけは有効成分が全て地面に落下した と仮定しても $0.05 \mathrm{gAI} / \mathrm{m}^{2}$ であり, それほど高くない. それ でも処理後のマダニの捕獲数が少なかったのは, 処理区外か らのマダニの侵入圧が弱かった可能性が考えられた。

\section{2）ダニ種間・発育段階と薬剤感受性}

マダニ種間での防除効果の違いとして, Schulze et al.（2000）は薬剤感受性や行動性の違いが要因になるとして いる. 今回, 試験期間中に採集されたマダニの多くはチマダ 二属であり, これらの感受性は概ね類似したものと想像され る.より大型のタカサゴキララマダニA. testudinarium Koch は処理7日，31日後に計2頭採集されたのみで，チマダニ属 との感受性の違いは不明であったが, Schulze et al.（2000） の示唆のように, 大きさや行動が異なるダニ種間では, 野外 散布時の効果が異なることは考えられるだろう. また, 殺虫 剂感受性は同一種の中では小型の幼虫ほど高く, 成虫は低い 傾向が経験的に知られるが，処理前に若干見られた幼虫は， 観察者によっては見落としがちであることなどから, その数 は効果判定に算入しなかった。作業者が歩きながら手動で噴 霧処理する方法は, 車載式噴霧器 (Mount and Whitney, 1984) やへリコプター散布（Schulze et al., 1994）に比べて撒きムラ が少ないため, 集合性の強い幼虫数が多い時期に, その数も 算入して効果判定すると, より高い駆除効果となった可能性 がある. 今般のSFTSのように発症時期やベクターマダニの 発育に季節性が見られる場合（国立感染症研究所, 2014）に は, 薬剤散布等の対策時期も自ずと決まるが, 地域によって 駆除対象種は変わりうるので, マダニの薬剤感受性の種間 差, 効果判定法の検証が必要である.

\section{謝 辞}

本研究実施に当たり, 住化エンバイロメンタルサイエンス (株)中尾加津巳氏, 住友化学(株)岡本央氏, 日本液炭(株)芳村健治 氏, 田中崇氏, フマキラー・トータルシステム侏丸山尚氏, 三井化学アグロ(株小曽根努氏, 鵬図商事(株五十嵐真人氏, 勝 永秀人氏には薬剤・散布機器提供ならびに薬剤散布のご協力 を頂いた。 またサンケミファ(株)、大日本除蟲菊(株各社からも 薬剤のご提供を頂いた．さらに東京大学千葉演習林には調査 フィールド使用の便宜を賜り, 同大学農学生命科学研究科の 松本芳嗣, 三條場千寿両博士には調査地選定の労を賜った. 日本環境衛生センター新庄五朗氏には文献をご教示頂いた。 各関係者に厚くお礼申し上げます。なお，本研究の一部は厚 生労働科学研究費補助金 新型インフルエンザ等新興・再興 感染症研究事業（H25-新興-指定-009）の助成を受けて行わ れた。

\section{文献}

浅田正彦. 2011. 千葉県におけるニホンジカの分布域および 個体数推定（2010年）.千葉県生物多様性センター研究報 告, 3: 16-27.

Bharadwaj, A., Stafford, K. C. III and Behle, R. W. 2012. Efficacy and environmental persistence of nootkatone for the control of the blacklegged tick (Acari: Ixodidae) in residential landscapes. J. Med. Entomol., 49: 1035-1044.

Bloemer, S. R., Mount, G. A., Morris, T. A., Zimmerman, R. H., Barnard, D. R. and Snoody, E. L. 1990. Management of lone star ticks (Acari: Ixodidae) in recreational areas with acaricide applications, vegetative management, and exclusion of whitetailed deer. J. Med. Entomol., 27: 543-550.

Dolan, M. C., Jordan, R. A., Schulze, T. L., Schulze, C. J., Manning, M. C., Ruffolo, D., Schmidt, J. P., Piesman, J. and Karchesy, J. J. 2009. Ability of two natural products, nootkatone and carvacrol, to suppress Ixodes scapularis and Amblyomma americanum (Acari: Ixodidae) in a Lyme disease endemic area of New Jersey. J. Econ. Entomol., 102: 2316-2324.

Hughes, T. N., Richardson, A. G., Hoel, D. F., Mejeoumov, T., Farooq, M. and Stoops, C. A. 2014. Suppression of Amblyomma americanum (Ixodida: Ixodidae) for short-term field operations utilizing cypermethrin and lamda-cyhalothrin. J. Med. Entomol., 51: 709-712.

北岡茂男, 藤崎幸蔵. 1971. オウシマダニとフタトゲチマダ 二に対する駆除剤の効力検定. 防虫科学, 36-I: 27-34.

国立感染症研究所. 2014. 重症熱性血小板減少症候群. 国 立感染症研究所 HP. [accessed Dec 2, 2014] http://www.nih. go.jp/niid/ja/stts/3143-sfts.html

厚生労働省. 2013a. マダニの防除を標榜する殺虫剂の取り 扱いについて。薬食審査発 0626 第 1 号. 平成 25 年 6 月 26 日厚生労働省医薬食品局審査管理課課長通知. [accessed Feb 9, 2015] http://wwwhourei.mhlw.go.jp/cgi-bin/t_docframe2. cgi? MODE $=$ tsuchi $\& D M O D E=$ SEARCH $\&$ SMODE $=$ NORMAL $\&$ KEYWORD $=\% 83 \% 7 \mathrm{~d} \% 83 \% 5 \mathrm{f} \% 83 \% 6 \mathrm{a} \& \mathrm{EFSNO}=6393 \& \mathrm{FILE}$ $=$ FIRST $\&$ POS $=0 \&$ HITSU $=10$

厚生労働省. 2013b. マダニの防除を標榜する殺虫剤の取扱 いに係る質疑応答集（Q\&A）について。平成25年6月26 日厚生労働省医薬食品局審査管理課事務連絡. [accessed Feb 9, 2015] http://wwwhourei.mhlw.go.jp/cgi-bin/t_docframe2. cgi $\mathrm{MODE}=$ tsuchi $\&$ DMODE $=\mathrm{SEARCH} \& \mathrm{SMODE}=\mathrm{NORMAL}$ $\&$ KEYWORD $=\% 83 \% 7 \mathrm{~d} \% 83 \% 5 \mathrm{f} \% 83 \% 6 \mathrm{a} \& \mathrm{EFSNO}=6395 \&$ FILE $=$ FIRST $\&$ POS $=0 \&$ HITSU $=28$

Mikami, N., Imanishi, K., Yamada, H. and Miyamoto, J. 1985. Photodegradation of fenitrothion in water and soil surface, and its hydrolysis in water. J. Pestic. Sci., 10: 263-272. 
森啓至，藤曲正登. 1994. 千葉県におけるマダ二類の分布と 季節消長.ダニと疾患のインターフェイス（SADI組織委 員会編), pp. 25-28. YUKI書房, 福井.

Mount, G. A. 1981. Amblyomma americanum: Area control of overwintered nymphs and adults in Oklahoma with acaricides. J. Econ. Entomol., 74: 24-26.

Mount, G. A. and Whitney, R. W. 1984. Ultralow-volume mists of chrorpyrifos from a tractor-mounted blower for area control of the lone star tick (Acari: Ixodidae). J. Econ. Entomol., 77: 12191223.

岡村正明，川村浩，宍戸亮，㱜田美智子，北岡正見． 1963. 1960 年秋富士山麓に発生した恙虫病の流行とBHC野外大 量散布の本流行に対する阻止効果について. 日本伝染病学 会雑誌，36: 540-546.

Sakata, S., Mikami, N. and Yamada, H. 1992. Degradation of pyrethroid optical isomers in soils. J. Pestic. Sci., 17: 169-180.

佐々木均, 市川ひろみ, 岩城和久, 椿洋一郎, 田村佳 子, 野上義隆. 1998. 放牧牛に寄生するマダニに対する fenpropathrinの防除効果. 酪農学園大学紀要, 22: 221-224.

Schulze, T. L., Jordan, R. A. and Hung, R. W. 2000. Effects of granular carbaryl application on sympatric populations of Ixodes scapularis and Amblyomma americanum (Acari: Ixodidae) nymphs. J. Med. Entomol., 37: 121-125.

Schulze, T. L., Jordan, R. A., Vasvary, L. M., Chomsky, M. S., Shaw, D. C., Meddis, M. A., Taylor, R. C. and Piesman, J. 1994. Suppression of Ixodes scapularis (Acari: Ixodidae) nymphs in a large residential community. J. Med. Entomol., 31: 206-211.

新庄五朗，伊藤靖忠，水谷澄。2013。薬剤概論. 住環境の害 虫獣対策（緒方一喜ら編著），pp237-318．日本環境衛生セ ンター, 川崎.

Stafford III, K. C. 2004. Tick Management Handbook. 66 p. The Connecticut Agricultural Experiment Station, New Heaven. [accessed Dec 2, 2014] available from: http://www.ct.gov/caes/ lib/caes/documents/publications/bulletins/b1010.pdf.

Tamura, Y., Tsubaki, Y., Terada, Y., Kohmoto, M. and Kamio, T. 2004. The efficacy of etoxazole against Haemaphysalis longicornis (Acari: Ixodidae), as a tick control agent. J. Med. Entomol. Zool., 55: 303-311.

角田隆. 2012. 千葉県から記録された中型・大型哺乳類寄生 性マダ二類. 千葉中央博自然誌研究報告, 12: 33-42.

吉田利男. 1975. 放牧牧野におけるマダ二駆除に関する生 態学的研究. 信州大学教養部紀要. 第二部, 自然科学, 9: 27-111. [accessed 2 Dec. 2014] https://soar-ir.shinshu-u.ac.jp/ dspace/bitstream/10091/4329/1/Liberal_arts_S09-04.pdf 